\title{
Indicadores para selecionar áreas agroturísticas: o desempenho dos atributos agropecuários, turísticos e de conservação ambiental
}

\author{
Indicators to select agri-touristic areas: the performance of agricultural, \\ touristic and environmental conservation attributes
}

\section{Bernadete da Conceição Carvalho Gomes Pedreira, Rozely Ferreira dos Santos, Eluan Alan Lemos Pocidonio}

\section{RESUMO}

0 agroturismo, atividade turística associada às práticas agropecuárias desenvolvidas no meio rural, requer estudos de viabilidade e planejamento para que possa se desenvolver sob condições socioeconômicas e ambientais sustentáveis. Para tanto, um primeiro passo é o levantamento e a integração de indicadores que efetivamente apontem as áreas mais adequadas para explorar essa atividade. Desta forma, este estudo teve por objetivo selecionar e avaliar um conjunto de indicadores que, ao serem integrados, pudessem evidenciar as áreas de máxima potencialidade (aptidão) agroturística de um território, reconhecidas não só pelas suas qualidades agrícolas, mas pela sua capacidade de atendimento às demandas de turistas rurais e contribuição à manutenção da conservação ambiental. A área de estudo foi a bacia hidrográfica do Rio Mogi-Guaçú (SP, Br), cujos municípios compõem o "Circuito Paulista das Águas". Foram selecionados 14 indicadores a partir dos parâmetros comumente mencionados na pesquisa acadêmica e que melhor pudessem expressar a relação existente entre desenvolvimento rural, agroturismo e preservação ambiental. Os indicadores foram ponderados de acordo com sua importância ao agroturismo e a integração dos dados foi realizada utilizando um Sistema de Informações Geográficas (programas ENVI e IDRISI). Os resultados apontaram que cinco indicadores nortearam a seleção final das cidades de Socorro, Serra Negra e Águas de Lindóia como detentoras de maior potencial ao agroturismo. Também consideraram que a inclusão de maior quantidade de indicadores não favorece, necessariamente, a identificação das áreas meIhor qualificadas para o agroturismo.

PALAVRAS-CHAVE: Turismo Rural; Conservação Ambiental, Atributos Diagnósticos.

\begin{abstract}
The agri-tourism, tourism associated with agricultural practices developed in rural areas, requires planning and studies of feasibility for develop itself under environmental and socioeconomic sustainable conditions. For this, the first step is the survey and integration of indicators that are able to point effectively the most appropriate areas to explore this activity. Therefore, this study aimed to select and evaluate a set of indicators that being integrated, could evidence areas of maximum agritouristic potential (fitness) of a rural territory, recognized not only for its agricultural qualities, but for its ability to meet the demands of rural tourists and their contribution to the maintenance of environmental conservation. The study area was the Mogi-Guaçú River (SP, $\mathrm{Br}$ ) watershed, whose districts form the "Circuito das Águas Paulista". 14 indicators were selected from the parameters commonly mentioned in academic research and best express the relationship between rural development, agritourism and environmental preservation. The indicators were weighted according to their importance to agritourism and the integration of data was performed using a Geographic Information System (ENVI and IDRISI software). The results showed that five indicators guided the final selection of the cities of Socorro, Serra Negra and Águas de Lindóia as having the greatest potential to agritourism. They also found that the inclusion of a greater amount of indicators does not favor necessarily identifying areas best qualified for agritourism.
\end{abstract}

KEYWORDS: Rural Tourism; Environmental Conservation; Diagnostic Attributes. 


\section{Agradecimentos}

O presente estudo foi derivado da tese de doutoramento da primeira autora e realizado com o apoio das agências brasileiras de fomento à pesquisa: Conselho $\mathrm{Na}$ cional de Desenvolvimento Científico e Tecnológico/ CNPq e Coordenação de Aperfeiçoamento de Pessoal de Nível Superior/ CAPES.

Bernadete da Conceição Carvalho Gomes Pedreira: EMBRAPA Solos, Rio de Janeiro, RJ, Brasil.

Email: pedreira9@gmail.com

Link para o currículo Lattes: http://lattes.cnpq.br/1144523531145151

Rozely Ferreira dos Santos: Universidade Estadual de Campinas, Campinas, SP, Brasil. Email: roze@fec.unicamp.br

Link para o currículo Lattes: http://lattes.cnpq.br/2706953510433930

Eluan Alan Lemos Pocidonio: EMBRAPA Solos, Rio de Janeiro, RJ, Brasil.

Email: eluanlemos@yahoo.com.br

Link para o currículo Lattes: http://lattes.cnpq.br/8813373262056132

Data de submissão: 30 de maio de 2012

Data de recebimento de correções: 03 de dezembro de 2012

Data do aceite: 08 de abril de 2013

Avaliado anonimamente 